\title{
Empirical Study of Intergeneration Transmission of Factors among the Women Working in the Informal Sector
}

\author{
Rachita Rana \\ Maharaja Surajmal Institute, Guru Gobind Singh University, India
}

Copyright $\mathrm{C} 2019$ by authors, all rights reserved. Authors agree that this article remains permanently open access under the terms of the Creative Commons Attribution License 4.0 International License

\begin{abstract}
Women workers in informal sector contribute significantly towards the transmission of physical, financial, economic, social and cultural factors intergeneration. The attempts to give insight into how the factors such as economic condition, living conditions, basic amenities, reason for work, status in family financial conditions, social and working conditions are transmitted and how significant is the contribution of attributes when they worked as a child, and as an adult. The working women in informal sectors have neither change nor significant improvement in the factors under consideration despite working as child, adult and as they grew old. The objective of the paper is to find out the intergeneration transmission of factors depending on the stage of generation among the working women in informal sectors. The research methodology adopted is descriptive and explanatory in approach. Primary data has been collected through structured interview schedule. The sample size is 485 female workers working in informal sector. The research paper has implications for managers and researchers.
\end{abstract}

Keywords Intergeneration Transmission of Factors, Informal Sector, Attribute

\section{Introduction}

Human resource is neither exclusive nor is inevitable. All development ultimately encompasses the human development. It will also call for an answer that human progress will make the future look better. Looking towards the future progress, development and sustenance women have to be empowered socially, economically and financially. In India, unemployment is structural and is the result of a deficiency of capital and rising birth rate and the falling level of death rates. The rate of growth of population which was about $1.31 \%$ p.a. during $1941-50$ has risen to $1.93 \%$ during 1991-2001. Further it has been brought down to $1.76 \%$ during $2001-2011$. According to 2011 census, the total Indian population stood at a high level of 121.08 crore which was $17.5 \%$ of the world's total population. To maintain this $17.5 \%$ of world's population and more as currently population stands at 134.2 crores, India holds only $2.42 \%$ of total land area of the world. On other hand the capital formation is low. Therefore the labour force is either absorbed in agriculture sector or pushed towards informal sector. The informal sector creates employment opportunities and is more receptive of women. The gender biases in informal sector are the integral part of the society and manifests as malnutrition, illiteracy, exploitations, drudgery and impoverished status. These adverse effects of unequal opportunities and political power on development are all the more damaging because economic, political, and social inequalities tend to reproduce themselves over time and gets transmitted across generations. Such phenomenon has also been reported as "inequality traps." (UNDP 2006). The inequalities are apparent and generate a type of life cycle pattern as observed in most of the persistent disorder. If one learns and observes the real environment; it requires a multipronged approach to treat a chronic problem, be it medical, economic, social, etc. It requires rigorous prescriptive measures initially to counter from all sides even if there are marginal side effects. For example, malnourished mother gives birth to a malnourished child and this child growing under underprivileged conditions will be the bearer of malnourished future generation. This transmission of malnourishment gets into genetic makeup through gene mutation and is accrued as a normal process. In order to cure it strict intervention is mandatory. Similarly, the pattern of intergenerational transmission of factors breeding itself cancerously in the informal sector needs to be dealt in obligatory and multi-pronged manner before it gets conventional in occurrence of the economic 
system. National Commission for Enterprises and informal Sector (NCEUS 2007), has also depicted that there has been a shift in the women employment in the poor segment from the primary activities to employment in constructions, small scale enterprises, cottage industries, home employment, part time engagement and different service providers. Even the underprivileged children from families at the bottom of the wealth distribution do not have the same opportunities as children from wealthier families. So these disadvantaged female children can expect to earn less as adults because access to learning of skills or getting education is limited. There are hardly any opportunities to improve the earnings and prospective potentials because in the urban informal sectors, women work generally as labourers in unskilled occupations, traditional works, as domestic help or are self-employed. This paves way for future supply of labour for informal sector in adult hood especially in case of females both women and girl child. The proper knowledge of the economic, productive, financial/ material, social and cultural factors, employment, living and working conditions of the women workers in urban informal sectors responsible for the inter generation transmission is insufficient. The unexposed boom of urban informal sectors and the negligence towards the women employed causes continuous exploitation, breeds inequality, unemployables \& poverty that moves from Intra-generation to Inter-generation. In this study, attempt was made to address the issue and the role of women workers in the inter-generation transmission of economic, financial, productive socio-cultural factors.

The women workers are in the working age from 15-59 years (Census of India 2011, GOI). The individual who is offering their services for remuneration is termed as labour or worker. The National Commission for Enterprises in the Unorganized Sector (NCEUS), Government of India, in 2007, also defined informal workers as "those working in the informal enterprises or households, excluding the regular workers with social security benefits, and workers in the informal sector without any employment and social security benefits provided by the employers.

Approximately 94 percent of the work forces worked in the informal sector as the employment growth in the formal sector, public and private combined had declined during the period between 1994 and 2007. This primarily happened due to the decline of employment in the government sector and on other hand the labour force grew at a faster rate of 2.84 per cent than the work force (Economic Survey. 2010 - 2011, GOI) attributing to rise in unemployment rate. The increase of female Workforce Participation Rate (WPR) in urban areas suggests improved utilization of labour time primarily in informal sector but there has been decline in the productivity and efficiency. With respect to women it is further stated that the wage/ salary receipt decline is further aggravated in these sectors as these women are too weak to demand their rightful dues due to complacent attitude, destitute poverty, illiteracy, ignorance, socio-economic framework and well-being. The poor families on other hand are forced to depend on women's earnings which are less compared to men or may be the prime source of income for the family. The high cost of living, income drain, social mobilization, stressful living conditions, media influence and poor socio-economic conditions compel the women to work in informal sector and transmit the factors intra-generation and then inter-generation.

\section{Intergeneration Transmission of Factors in Informal Sector}

The problem of poverty is the most formidable one which is being faced by underdeveloped and developing countries including India. When a substantial segment of a society is deprived of the basic necessities of life and continues to live at the par subsistence level; it is said to be plagued with mass poverty. This mass poverty is absolute, scaled and relative (1), chronic (2) and transitory in nature. Just by making policies poverty cannot be reduced and in some areas may intensify. (3). Over a period of thirty years lasting since independence and up-to the early eighties, there has been little per capita income growth and no significant reduction in poverty. Official poverty estimates which were about $45 \%$ in the early 1950 s remained the same even in the early eighties. Since the eighties, India economic growth has been one of the fastest in the world. The growth rate jumped from the average of about $3.5 \%$ of a year in the 1970 s to about $6 \%$ during the 1980 s and 1990 s and for the year 2018 GDP growth rate averages around 6.6percent. The higher growth rates have helped significantly in the reduction of poverty. There is a strong link between economic growth, disposable income, literacy and poverty reduction. The transitory poverty becomes chronic and intergenerational if contributory factors are not checked. (4).

Now with the emphasis of the government on Skill India, Start up India, Make in India, Stand up India and other government initiatives has given fillip to Economic growth and generate employment opportunities. It has also widened opportunities and the resources for development. However, the poor may not be able to take direct advantage from the opportunities created by economic growth (5), (6). The growth has been good in service sector of India but in the agriculture sector it is much below expectation. This low performance and disguised unemployment generate migration to urban areas where the networking plays a major role and they then get some engagement in informal sector. (7) These migrants not only in India but also in other countries get gainfully engaged in informal sector with characteristics like easy entry, long hours of work, low wages, no social security, risk of sexual abuse, violence and low level of education,(6), Certain engagement in the informal sector 
are gender specific in urban areas of Delhi like domestic workers, beauty parlours, construction unskilled works, boutique and vendors(8). Infect another important observation is that the girl child is entrusted with the responsibility of household daily chores, child care duties of younger siblings and household management responsibilities (9), (10). The earnings are sufficient only for subsistence level of living and paves way for poverty.

Different economists define poverty in different ways. Revised Tendulkars' poverty line of Rs 673 in rural areas and Rs 860 in urban areas (based on 2009 - 10 prices) showed a decline in poverty ratio to 29.8 percent in 2009 10 as against 37.2 in $2004-05$. Rangarajan Committee adopted poverty line of Rs 972 in rural areas and Rs 1407 in urban areas and found 29.5 percent living below poverty line in 2011 - 12 as against 38.2 percent. (Competition Success Review September 2014).

There are discrepancies in the measurement of poverty; sometimes it is stated to be Rs 28.7 per capita, per day for urban areas and 22.42 for rural areas. $66^{\text {th }}$ round of NSSO Sample 2009 - 2010 provides a comparative realistic indicator for estimating poverty line and population below that is Rs 66 per capita, per day for urban areas and 35.10 for rural regions. This measurement results in estimated 64 percent of the rural population and 66.7 percent of the urban population to be below poverty line. These are projected on the expenditure population curve (Sunday Times, Apr 29 ${ }^{\text {th }}, 2012$, pp 1)

The urban poor with considerable time, residing in cities acquire distinct characteristics like living in slums, rural to urban migration, irregular employment, employment in informal sector, lack of economic opportunities, degraded environment, psycho-social problems (stress, insecurity, depression, violence, crime, drug \& alcohol addiction, source of child labor), etc. and major causes prevail in the social and economic structure. This then gets engrained as intergeneration transmission and intra generation transmission of factors.

\subsection{Inter-generation Transmission}

The inter-generation transmission of poverty referred to the ways in which a poor parent can 'transfer the conditions of poverty to his/her children'(5), (11). Despite extensive efforts 456 million (42\%) are below poverty line according to World Bank New poverty line is at 1.25 US \$ per day and Poverty ratio is $28.3 \%$ in rural areas and $25.7 \%$ in urban areas and may be attributed to intergeneration transmission. These poor people in India specially the women seek gainful engagement in informal sectors and contribute to the intergeneration transmission of factors and also exhibit intra-generation and intergeneration transmission (Figure 1).

A systematic attempt was made to study the role of women workers in urban informal sectors in IGT of factors and at the complete level taking into consideration maximum occupations like domestic, export houses, self-employed, contractual workers of construction, safai karamcharis and other related works. This negligence towards these women workers causes continuous exploitation. Despite immense exploitation virtual and real, the role of women in the inter-generation transmission of factors like poverty and under productive potential in the urban informal sectors may be considered as significant. These women are holding and strengthening the informal market structure, family structure and process of intergeneration transmission of poverty that is moving through being Intra-generation. Along with it, there is intergeneration transmission of poverty and under productive potential that is primarily through women workers (Young and Elder) to the girl child and there is occupational segregation and marginalization of informal female workers.(11) 
Child acquires the trades / semi-skills gradually and grows up as adult with minimum literacy and unemployables. Informal sectors provide potential employment and inadequate eamings to new entrants. These women get maried and carry out similar pattem of activities.

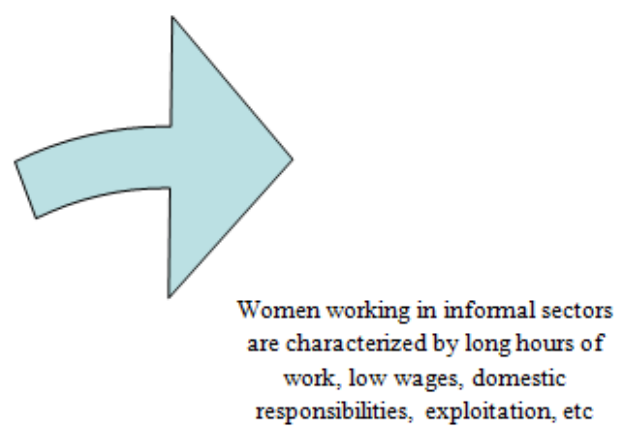

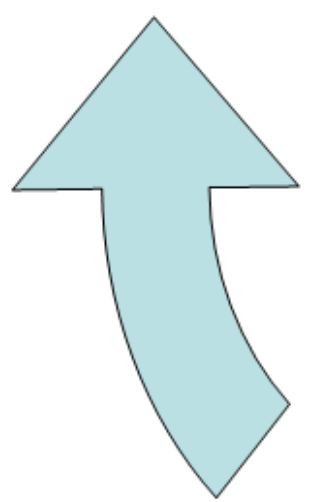

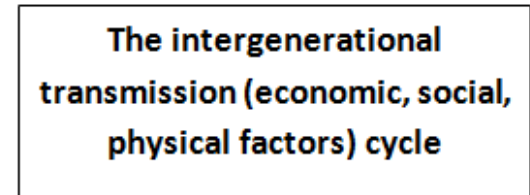

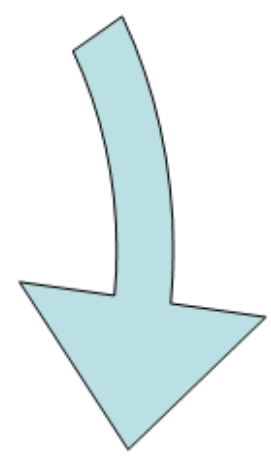

Prefers taking the child ( particularly the girl) to work along with her in order to avoid social and economic problems e.g juvenile delinquency, unhealthy environment, etc. if working at home as part time or piece rate starts occupying the child by providing the similar materials as play items, transmission of skills to next generation occurs.
Holds the responsibility of domestic chores, inadequate family income and children

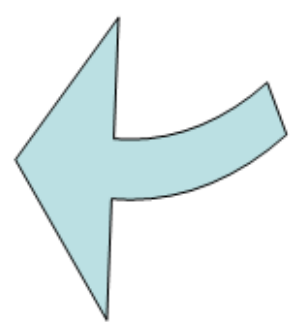

Source: Rana Rachita, Role of Women Working in the unorganized Sector in IGT of Poverty: A Study of Delhi. Himalaya Publications, Mumbai 2016 ISBN: 9789385958373

Figure1. Intergeneration Cycle of transmission of factors

\subsection{Factors as Determinants of Poverty: Intra and Intergeneration Transmission}

Inter generation transmission of poverty (ITP) is a process by which poor parents transmits poverty and disadvantage to their children (12). In fact it is also referred as tightest definition of chronic poverty where 'private' transmission of poverty from older generation of individuals and families to younger generation families (13), (14). This intergeneration transmission (IGT) is seen as a series of multiple vulnerabilities which include poor nutrition and health care, low levels of education, depletion of environment, insecure livelihoods, indebtedness, cultural norms, traditions and social practices.(15)(16). Besides vulnerabilities, there are range of structures, processes, parental education and livelihood strategies transmitting intergeneration and the resilience is critical for preventing the intergeneration transmission (17) ( (18) .Few are more specific to developing country like India; migration patterns, socio-legal entitlement norms, informal market structure and social security and services. No doubt the women workers are significantly working in the informal sectors of metropolitan Delhi. Considering the limited available infrastructure, time, financial constraints it was not possible to study each sector employing these women. In the study many terms like labor, demand for labor, employment in informal sector, working and employment conditions, intergeneration transmission of poverty and other factors, have been used interchangeably and in inter-disciplinary context so as to bring forward the optimum conveniences of expression.(08). The broad categories of the factors are given below: 
i) Economic Factors: Family Income, material and financial assets, low productivity jobs, terms and conditions of employment that included wages, deductions of wages, nature of work, the age, efficiency, cost expense towards health and hygiene, source of supply, nature of work, lack of social security, low level of education, etc. Demand and Supply to labor market of Informal Sector: The main impact of migration from rural areas to urban areas are: increase in urban population and slums, decrease in wage bargaining power, demand for labor lags behind the supply, deteriorated health and life expectancy, forceful entry of children into doing work, etc. (4)(9), (11)

ii) Social factors: Culture, value, caste and social systems which poverty creates, breeds and transmits in the population. Other Social factors like sex suitability, family compulsions, complacency, social background, lack of access to social services and basic amenities, insecurity, male dominance, force to supplement the meager family earnings, high cost of living, inadequate family income, low level of literacy, impact and awareness of Poverty Alleviation Programmes, etc. 19, 20, 21.

iii) Physical factors:

a. Living conditions: The assessment included drinking water, sanitation, sewage, dwelling units, facilities at dwelling unit, garbage collection, etc.

b. Working Conditions: The assessments of working conditions of women laborers were also important in order to have full knowledge of employment. The working conditions implied the duration of working hours, nature of work, terms and conditions of payment, and overtime payment. The working conditions also included the physical environment and surroundings at place of work. In case of women workers, special observation was made with respect to separate toilet facilities and security at place of work.

\section{Methodology}

The research design was descriptive and explanatory in approach. The descriptive research brought forward the situational analysis and described various aspects of women workers working in the informal sector. The applied and experimental study described the role of women in intergeneration transmission of factors of under productive potential and poverty. The universe of study comprised all the women working in the informal sectors of Urban Delhi like domestic help, construction site, home based industries, utensil barters, rag pickers, street vendors, etc . The sample was drawn as mentioned below:

Women aged 15 years and above (maximum 59 years) working in the informal sectors of Delhi metropolitan city.

\subsection{Inclusion Criteria}

- Only those families were considered and included for the research where the young and the adolescent are/had been working and the elder women may have worked or is working currently in the informal sectors in Delhi metropolitan city.

- Secondly, the women belonged to the very low to low income families. The three categories of low income that was included for the study are given below poverty line: The monthly per capita income is demarcated as Rs 454.11 or Rs 67 per day in urban areas (www.gov.delhi.in) and the annual family is also below poverty line.

- Above poverty line but annual family income is less than Rs 55,000.

- Third category will be annual family income between Rs 55,000 to one lakh depicting high vulnerability.

Further, the Multi staged stratified judgmental sampling method was used to draw the required sample. Here the researcher generated wider understanding of social processes and social action. The poverty aspect was dealt by considering the inclusion criteria of very low to low family income. The BPL families across the three segments were representative of chronic poverty and above or on Poverty line families up to Rs One lakh P.A family income were representative of transitional poverty. This is so stated because average size of the family according to Delhi economic Survey is 4.1.

The Sample size Distribution N=485 Number for the purpose of study: Data was collected through both primary and secondary sources. The study was based on primary data in order to get most reliable, original, correct, prompt information and explore questions in depth: What are the factors that are transmitted (focusing on economic, human, social-cultural, financial/ material and environmental/ natural, etc)

\section{Results and Interpretation}

Table 1. Economic Conditions Improved in Monetary terms only (five point Likert scale for poverty ( 1 is destitute poverty and 5 transitory poverty bar.) $(\mathrm{N}=485)$

\begin{tabular}{|l|c|c|}
\hline & Mean & S.D. \\
\hline As a child only & 1.71 & 0.734 \\
\hline As a young Women & 2.09 & 0.754 \\
\hline
\end{tabular}

Table 1A. Comparison of economic conditions of women (15 years and above) at present and when she was a child (5-14 years) - Partial $\mathrm{t}$ - test. $(\mathrm{N}=485)$

\begin{tabular}{|l|l|l|l|}
\hline Variable & Mean & Standard Deviation & t Value \\
\hline As a child & 1.7159 & \pm .834 & \multirow{2}{*}{$8.25^{* *}$} \\
\cline { 1 - 3 } As a young women & 2.1058 & \pm .787 & \\
\hline
\end{tabular}

** - Significant at .01 level 
Table 2. Contribution of Individual Earnings to the Family Income $(\mathrm{N}=485)$

\begin{tabular}{|l|c|c|}
\hline & Frequency of Yes as a response & Percent \\
\hline As a Child only & 478 & 98.6 \\
\hline As a women & 7 & 1.4 \\
\hline
\end{tabular}

Table 3. Wages earned by the respondent when worked as a child $(\mathrm{N}=485)$

\begin{tabular}{|l|c|c|}
\hline Earnings in rupees (INR) per month & Frequency & Percentage \\
\hline Upto 700 & 62 & 13.8 \\
\hline $701-2000$ & 343 & 70.7 \\
\hline $2001-4000$ & 78 & 16.1 \\
\hline $4001-6000$ & 2 & 0.4 \\
\hline $6001-8000$ & 0 & 0 \\
\hline $8001 \&$ above & 0 & 0 \\
\hline
\end{tabular}

Table 3A. Wages earned by the respondent when worked as a women $(\mathrm{N}=485)$

\begin{tabular}{|l|l|l|}
\hline Earnings in rupees (INR) per month & Frequency & Percentage \\
\hline Upto 700 & 10 & 2.1 \\
\hline $701-2000$ & 79 & 16.3 \\
\hline $2001-4000$ & 250 & 51.5 \\
\hline $4001-6000$ & 129 & 26.6 \\
\hline $6001-8000$ & 12 & 2.5 \\
\hline $8001 \&$ above & 5 & 1.5 \\
\hline
\end{tabular}

Table 4. Living Conditions as Child $(\mathrm{N}=485)$

\begin{tabular}{|l|c|c|}
\hline Type of Dwelling unit & Frequency & Percentage \\
\hline Jhuggi & 196 & 40.4 \\
\hline Kachha & 177 & 36.5 \\
\hline Semi Pacca & 54 & 11.1 \\
\hline Hutments & 15 & 3.1 \\
\hline Pucca & 40 & 8.2 \\
\hline On Sharing Basis & 3 & 0.6 \\
\hline
\end{tabular}

Table 4A. Living Conditions as a Women $(\mathrm{N}=485)$

\begin{tabular}{|l|c|c|}
\hline Type of Dwelling unit & Frequency & Percentage \\
\hline Jhuggi & 216 & 44.5 \\
\hline Kachha & 54 & 11.1 \\
\hline Semi Pacca & 91 & 18.8 \\
\hline Hutments & 3 & 0.6 \\
\hline Pucca & 108 & 22.3 \\
\hline On Sharing Basis & 3 & 2.7 \\
\hline
\end{tabular}

Table 5. Security at Work Place as a child $(\mathrm{N}=485)$

\begin{tabular}{|l|c|c|}
\hline $\begin{array}{l}\text { Factors contributing to } \\
\text { security at place of work }\end{array}$ & $\begin{array}{l}\text { Frequency (yes as } \\
\text { a response) }\end{array}$ & Percentage \\
\hline $\begin{array}{l}\text { Working along with family } \\
\text { members }\end{array}$ & 214 & 79.2 \\
\hline Work from home & 46 & 9.5 \\
\hline $\begin{array}{l}\text { Work with other women } \\
\text { co-workers }\end{array}$ & 16 & 3.3 \\
\hline Security from employer & 38 & 7.8 \\
\hline Others & 1 & 0.2 \\
\hline
\end{tabular}

Table 5A. Security at Work Place as a Women $(\mathrm{N}=485)$

\begin{tabular}{|l|c|c|}
\hline $\begin{array}{l}\text { Factors contributing to } \\
\text { security at place of work }\end{array}$ & $\begin{array}{l}\text { Frequency (yes as } \\
\text { a response) }\end{array}$ & Percentage \\
\hline $\begin{array}{l}\text { Working along with family } \\
\text { members }\end{array}$ & 238 & 49.1 \\
\hline Work from home & 51 & 10.5 \\
\hline $\begin{array}{l}\text { Work with other women } \\
\text { co-workers }\end{array}$ & 113 & 23.3 \\
\hline Security from employer & 81 & 16.7 \\
\hline Others & 2 & 0.7 \\
\hline
\end{tabular}

Table 5B. Comparison of Basic amenities availability to women (15 years and above) at present and when she was a child (5-14 years)

\begin{tabular}{|l|l|}
\hline Variable & $\begin{array}{l}\text { Currently woman and When the } \\
\text { woman was a child }(\mathrm{N}=485)\end{array}$ \\
\hline Drinking water & $\begin{array}{l}\text { Chi square } \chi 2=21.95, \\
\mathrm{p}<.01, * * \text { Significant }\end{array}$ \\
\hline Electricity & $\begin{array}{l}\text { Chi square } \chi 2=17.38, \mathrm{p}=.01^{* *}, \\
\text { Significant }\end{array}$ \\
\hline Toilets and washroom & $\begin{array}{l}\text { Chi square } \chi 2=18.37, \mathrm{p}=.01^{* *}, \\
\text { Significant }\end{array}$ \\
\hline $\begin{array}{l}\text { Existence of Sewage } \\
\text { system }\end{array}$ & $\begin{array}{l}\text { Chi square } \chi^{2}=47.62, \mathrm{p}=.01^{* *}, \\
\text { Significant }\end{array}$ \\
\hline $\begin{array}{l}\text { Regular garbage } \\
\text { collection facility }\end{array}$ & $\begin{array}{l}\text { Chi square } \chi 2=79.37, \mathrm{p}>.05, \text { Not } \\
\text { Significant }\end{array}$ \\
\hline
\end{tabular}

\section{Intra-generation to Inter-generation Transmission of Factors}

\subsection{Economic Conditions}

The poverty is a complex phenomenon in its content and scope. It is diversified, intensive and intrinsically related to socio-cultural, socio-political and socio-economic, physical and environmental factors. Poor Monetary Conditions has been analyzed by categorization. The very poor category represented the destitute poverty and chronic poverty. Poor represents the category of the women who are living in deprived conditions and are below the poverty line as per Indian norms. Little better are the respondents who are on poverty line and somewhat better are the ones who are in the transitory pattern i.e. sometimes, below poverty line, sometimes on or above poverty lines but are highly vulnerable. Over a period of time their economic conditions improved as a result of enhanced earnings when they were young women but still on the scale are poor and living under poverty \&susceptibility.

- Parents influence the children's overall development. The overall development of the child does require investment of time, money, family obligations, helping them learn, expenditure on their education, etc. but all these are directly related to the family income. This means that low economic status and family income of the adult deprives the child of the development pushing them to work in the informal sector and contribute to the family income. The reasons attributed to it is that these women as a child 
did not get wage payment specially in the rural areas where they were though productively employed in activities like cattle rearing, working on farm and non-farm activities with family members.

Therefore to conclude it may be stated that the no change over the period of time is indicated and being persistent is indicative of Intra-generation existence and continuous struggle. Further, as per the inclusion criteria with purview it paves way for inter-generation depiction. Similar findings have been reported in other studies.(23)

- Transmission of Financial matters: The stagnant state of earning ability and minimal to financial assets being transmitted from their adults is an indicator of decline in standard of living. This deterioration further indicates hard pressing pressures, undue harassment and atrocities the women have to face. This state when clubbed with ever growing high cost of living makes the life experiences even bitterer. These experiences are shared in its crude form by their children as well. They also get acclimatized to the situations and accept it as way of life.

- It also indicates there is a mark shift in the earning ability as a woman when compared intra-generation to child earning. But if compared to the current child labor and these women as a child, the pattern of earning emerges to be nearly same indicating no improvement in terms of wage payment over a period of time and hence further deteriorating their living conditions.

- The prime reasons for working in the informal sector by these women are poverty. The process of poverty transmission is through poverty traps and transfers mainly through adult women to the girl child and then through this girl child when grows up to its next generation as there is no change that is significant in the parameters (economic, social, cultural, productive potential, environmental (living, physical work environment) except the absolute numbers. This situation when compared to the current women when she was a child did not show any significant difference in their state of poverty. The family drew economic disadvantage from the then elder women being children hampering their overall growth, health issues, earning abilities etc. Whereas when compared with the reason to work there is a significant difference between the women and when she was child. The woman primarily works as an individual to supplement the family income.

- Meeting the demands of the male members of the family has emerged to be one of the main reasons for the work across all the generations be it the child, young women or the elder. The situation is graver in Northern India due to patriarchal system and male dominance prevalence. Therefore the women have always been used in some way or the other to meet and fulfill the habitual demands. Further there has been significant difference in this aspect whether she is a child, elder women or young women. It's because the male relationship changes from father or brother to husband and then the sons.

- According to the study, it is revealed that the significant difference between child, young and elder women prevails with respect to being habitual workers and accepting it as an integral part of life transmitting intra-generation and then moving intergeneration through socioeconomic parameter and because of the insensitivity of the elders towards child work. It is also perceived by the parents and the grandparents that education is not going to serve as pathway out of poverty because there are hardly any employment opportunities for this strata of population but the wage earning opportunities extended by informal sector does help them at least to meet the basic needs and they being habitual to working in these activities and sector accept it. Thus showing the transmission of the factors, constraints, resources, habitual workers from adults to the child.

\subsection{Living Conditions}

Living conditions and neighborhood was observed and definitely affects the probability of Intra-generation transmission to intergeneration transmission. It also influences the prospects of breaking out of chronic poverty or deprivations and constraints. Therefore the inheritance in the form of material/ asset transfer is done on the basis of ownership rights and its right transfer to the next generations is affected.

- In the Study, it has been revealed by the young women that as compared to when she was a child that there is significant difference in the availability of drinking water, electricity, toilets, sewage system because the perceived comparison is with situation of their native villages as maximum respondents are migrants from neighboring states like Uttar Pradesh, Rajasthan and other states like Gujarat and Bihar. But no change has been revealed with respect to garbage collection. But the elder women who have been residing in Delhi for long duration express that there is no significant change in the availability of drinking water, electricity, toilets, Sewage systems, and garbage collection. This all indicates long prevalence of these factors. Now the probability is that the children and grandchildren of these elder women are living with same basic amenities. The elder women expressed that their is significant difference with respect to the availability of drinking water facilities, electricity, toilets, Sewage systems, and garbage collection at dwelling premises as compared to when she was young women. This inadequacy and lack has reduced and has almost halved with respect to toilets in last decade (TOI, May $8^{\text {th }}, 2012$ ). 


\subsection{Working Conditions}

- Population explosion, poverty and diminishing employment opportunities in organized sectors have resulted in push of workers towards informal sectors and thus their exploitations. The employers prefer women because they are submissive, docile and less demanding. They are illiterate, unskilled and unaware. Therefore, they can work for long hours with low wages, no bonus and other work related benefits and facilities. The prevailing socio-economic conditions force them to continue to be in this sector because if they are deprived of these meager earnings, it will further worsen their living conditions. Not only this, migrating to cities like Delhi and finding paid work is the way to escape from destitution and abject poverty. In fact women of such households constitute the source of supply to informal sector and in turn this sector gives them labor opportunities with earning potential though meager. As a result there is persistence of work conditions, this then moves intergeneration and then poverty. The poverty grows, becomes intense with occurrence of negative events like illness, poor health, stringent cultural practices, etc.

\subsection{Socio - Cultural Factors}

Government and various agencies working to combat poverty, whereas the role of mother or the grandmother in the transmission intergeneration has been overlooked as impetus to break the cycle of poverty transmission. In fact the socio-cultural factors are intrinsically interrelated with poverty and its persistence and the transmitting intergeneration. Therefore it implies that social intra-conflict needs to be addressed. Though we talk and claim gender equality, empowerment, but in our society the male arrival in northern India to the family is welcomed and that of female child, is a matter of grief. Therefore, it is essential to realize the seriousness of cruelties, disparities and violence inflicted on women.

\section{Conclusions}

There are hardly any opportunities to improve the earnings and potentials because in the urban informal sectors, women work generally as laborer in unskilled occupations, traditional works and work as domestic help. They are not offered fair wages and decent terms of work. These female (women and girl child) workers cannot get away from the responsibilities of domestic work at home. The proper knowledge of the economic, social and cultural factors responsible for the chronic conditions of the female workers in urban unorganized sectors is insufficient but have changed considerably due to developmental and policy changes. But in developing countries like India they have negligible control over vital issues and decision making. The gender bias is at all levels starting from inutero (Female foeticide) to missing women, inequalities; discriminations are transmitted from generation to generations, like a genetic disorder. These women working in the informal sector begin work as children and are in the age group of $16-25$ years. They are mothers or mother in-laws of women work force in informal sector. They Engage the children at home, while the young works they transfers skills to these growing children without human intervention directly. The gainful engagement dips after 41 years due to their involvement in rearing up the grandchildren. No correlation in this group between education and wage earnings, majority who reconcile to the fact of under productivity and poverty.

The unit of analyses was Female across the three generations i.e. as a child, young woman and elder woman, in the transmission of factors. It was found that poverty can also be transmitted within, between or through the community sphere. In order to deal with such problem, it is suggested that there should be involvement from all, government, NGOs, social workers, academicians, etc. These people should be made aware of the exploitation, underachievement, and it's inter generation transmission that restricts growth potentials. Finally, the employers though employing these women should educate them not to involve the next generation rather they should send them to schools and vocational centers. Further the direction of factors and poverty transmission should be highlighted not only from the older generation to the younger generations rather from younger to older generation as well due to rise in social unrest, aggression, intolerance, addictions, drug abuses and other materialistic demands.

\section{REFERENCES}

[1] Boggess S, Corcoran M, Jenkins SP. Cycles of Disadvantage? Wellington: Institute of Policy Studies; 1999.

[2] Shepherd A. Understanding and Explaining Chronic Poverty: An Evolving Framework for Phase III of CPRC's research, Overseas Development Institute (ODI) London, UK: CPRC Working Paper 80, Chronic Poverty Research Centre; 2007.

[3] Lucia DC, Joanita M. Evolution of Gender and Poverty Dynamics in Tanzania. Working Paper, No. 203. Chronic Poverty Research Centre; May 2011.

[4] Kate B. Empirical Approaches to The Study of Intergenerational Transmission of Poverty (Research Summary). Chronic Poverty Research Centre; October 2008. Report No.: 4.

[5] The Chronic Poverty Report. Escaping Poverty Traps. Chronic Poverty Research Centre; 2008-09.

[6] Verner D, Alder E. Youth at Risk, Social Exclusion, and Intergenerational Poverty Dynamics: A New Survey Instrument with Application to Brazil. In World Bank 
Policy Research Working Paper 3296; 2004.

[7] Mitra A. Informal Sector, Networks and Intra-City Variations in Activities- Findings from Delhi Slums. RURDS. 2004 July; 16(2).

[8] Rana R. Working Women in Informal Urban Economy New Delhi: Sunrise Publications; 2009.

[9] Rana R. Girl Child Labour New Delhi: Manak Publication; 2000.

[10] Dodson L, Dickert J. ‘Girls' Family Labour in Low-Income Households: A Decade of Qualitative Research. Journal of Marriage and Family. 2004; p. 318-332.

[11] Rana R. Role of Women Working in the unorganised Sector in Intergeneration Transmission of Poverty (IGT): A Study of Delhi Mumbai: Himalaya Publications; 2016.

[12] Castañeda T, Aldaz-Carroll E. The Intergenerational Transmission of Poverty: Some Causes and Policy Implications. In Inter-American Development Bank; 14 March, 1999.

[13] Moore K. Frameworks for understanding the intergenerational transmission of poverty and well-being in developing countries. In CPRC Working Paper 8; 2001; International Development Department, School of Public Policy, University of Birmingham.

[14] Harper C, Marcus R, Moore. Enduring Poverty and the Conditions of Childhood: Lifecourse and Intergenerational Poverty Transmissions. World Development. 2003; 31(3): p. 535-554.

[15] Bhargava P, Mathur K, Rajagopal S. Understanding Chronic Poverty in Rajastan. CHIP Report 16. London: 2005.

[16] Bird K. The Intergenerational Transmission of Poverty: An Overview. In Chronic Poverty Research Centre-Working Paper; 2007.

[17] Kate B, Kate H. Conflict, Education and The Intergenerational Transmission of Poverty in Northern Uganda. Project Briefing. Chronic Poverty Research Centre; August 2009. Report No.: 23.

[18] Stephen PJ, Thomas S. The Intergenerational Transmission of Poverty in Industrialized Countries. In Working Paper No. 75; 2007: Chronic Poverty Research Centre.

[19] Krishna A. Characteristics and Patterns of Intergenerational Poverty Traps and Escapes in Rural North India. In Chronic Poverty Research Centre-Working Paper No. 189; April 2011.

[20] Bird K. How is poverty transmitted intergenerationally and what might be done to stop it in its tracks? In Chronic Poverty Research Centre's international conference: Ten Years of 'War Against Poverty': What have we learned since 2000 and what should we do 2010-2020?; 2010.

[21] Bird K, Higgins K. Stopping the Intergenerational Transmission of Poverty: Research Highlights and Policy Recommendations. In Chronic Poverty Research Centre-Working Paper, No. 214; July 2011.

[22] Briony S. Intergenerational Transmission of Poverty in Sub-Saharan Africa. CPRC Working Paper 59, CPRC Annotated Bibliography No. 3. ; 2006.
[23] Machin S. Intergenerational Mobility and Childhood Disadvantage. [Online]. Available from: http://www.qub.ac.uk/nierc/documents/Machin.pdf. 